\title{
New record of Parsteres pilosus Gadelha, Nunes \& Oliveira, 2016, a rare species from a monotypic doryctine genus (Hymenoptera: Braconidae)
}

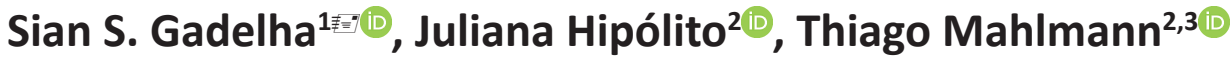

${ }^{1}$ Departamento de Biologia, Universidade Federal de Rondônia - UNIR, Porto Velho, Rondônia, Brazil. ${ }^{2}$ Instituto Nacional de Pesquisas da Amazônia - INPA, Manaus, Amazonas, Brazil. ${ }^{3}$ Programa de Pós-Graduação em Entomologia - PPG-ENT, Instituto Nacional de Pesquisas da Amazônia - INPA, Manaus, Amazonas, Brazil.

莑我Corresponding author: siangadelha@gmail.com

Edited by: Daniel Aquino

Received: July 21, 2020. Accepted: August 24, 2020. Published: September 11, 2020.

Abstract. Despite the huge diversity of Doryctinae, with about 3,000 species estimated, the subfamily also has about $30 \%$ of its approximately 205 genera as monotypic. Most of these monotypic genera are known from a few specimens used to describe its species and then remain without further records. Here we were able to enlarge the distribution knowledge of a monotypic genera making the first record of Parsteres pilosus Gadelha, Nunes \& Oliveira, 2016, to the Atlantic Forest biome at Salvador, Bahia, Brazil.

Keywords: Ichneumonoidea, Doryctinae, Atlantic Forest, Amazon Forest, Cerrado.

The subfamily Doryctinae is mainly composed by idiobiont parasitoids of wood-boring beetle larvae (Marsh 2002) and it is known as one of the most diverse subfamilies of Braconidae with about 205 genera described (Braet 2016) and about 3,000 species estimated. The family has a world wide distribution, and it is particularly diverse at the tropics (Marsh 1997). Despite the well-known distribution of the family, the same cannot be said about all of its genera, while some are very abundant as Heterospilus Haliday, 1836, and Spathius Nees, 1819 with more than 400 species each (Marsh et al. 2013; Yu et al. 2016; Zaldívar-Riverón et al. 2018) and therefore with a good understanding on its distribution, most genera have less than 10 species described, and actually about 60 of them are monotypic (Braet 2016). Although we cannot be sure about species rarity (as in some cases it could be a reflection of insufficient collecting), data present so far suggests that apart of some exceptions, these monotypic genera are composed of rare species known from few specimens, sometimes only by the holotype, and therefore their distribution tends to be considered endemic/restrict. In this sense, new data on the distribution of rare species are important to provide a more reliable knowledge of their real distribution, therefore enabling future efforts in order to preserve and study them.

Since its description, no more records of Parsteres Gadelha, Nunes \& Oliveira, 2016 specimens were made and it was believed that the genus distribution was limited to the Brazilian Amazon forest and North Cerrado. In this study we report the occurrence of Parsteres pilosus Gadelha, Nunes \& Oliveira, 2016 in Brazilian Atlantic Forest Biome (Fig. 1A), based on a specimen collected at Salvador, Bahia state, Brazil, in a residential area $\left(12^{\circ} 57^{\prime} 1^{\prime \prime} \mathrm{S} ; 38^{\circ} 24^{\prime} 3^{\prime \prime} \mathrm{W}\right)$ approximately 800 meters away from a fragment of Atlantic Forest known as Parque Metropolitano de Pituaçu, therefore expanding the distribution range of the genus to that biome. New and future studies should explore this taxon status of rarity as their occurrence in multiple biomes could suggest insufficient collecting. The specimen was deposited in the Invertebrates Collection of Instituto Nacional de Pesquisas da Amazônia (INPA). Photomicrographs were prepared using a Leica M205A coupled with a Leica DMC4500 and stacked using the software Leica Application Suite V4.10.0 Interactive Measurements, Montage.
The distribution map was built using the online software SimpleMappr (Shorthouse 2010).

Parsteres pilosus Gadelha, Nunes \& Oliveira, 2016

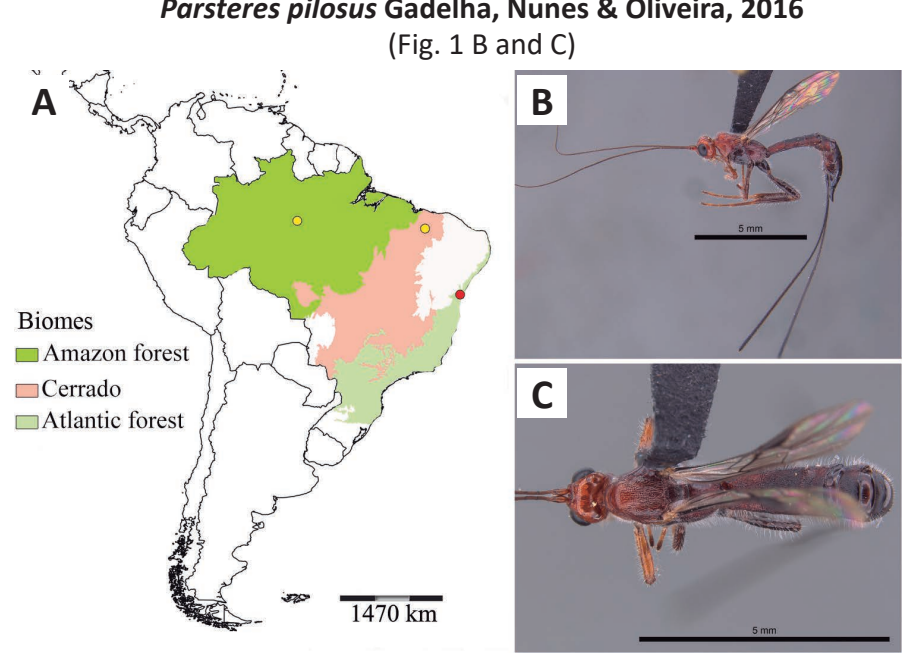

Figure 1. Parsteres pilosus Gadelha, Nunes \& Oliveira, 2016 and its occurrence. Map of South America with geographic records of P. pilosus, yellow dots represent previous records and red dot the new record made at this work (A). $P$. pilosus in lateral habitus (B) and dorsal view (C).

Parsteres pilosus Gadelha, Nunes \& Oliveira, 2016: 361. [Type species of Parsteres Gadelha, Nunes \& Oliveira, 2016; Holotype deposited at INPA]

Geographic records. Brazil (Amazonas, Bahia, and Maranhão).

Material analyzed. BRA, Bahia, Salvador, Bairro Patamares, Cond. Colina C, $12^{\circ} 57^{\prime} 1^{\prime \prime}$ S, 38 $24^{\circ} 3^{\prime \prime}$ W, 05.xi.2018, T.Mahlmann \& J.Hipólito Leg. (1ㅇ INPA).

Comments. The monotypic genus Parsteres Gadelha, Nunes \& Oliveira, 2016, was described from four Brazilian specimens, two of which belong to the Amazon rainforest, a female from Amazonas state identified as $P$. pilosus, and a male from Roraima state which was not assigned to the same species, and the other two specimens of $P$. 
pilosus (which includes the holotype) collected in an ecotone between the Amazon Forest and Cerrado in the Área de Proteção Ambiental do Inhamum (Environmental Protection Area of Inhamum or APA of Inhamum), which is located in the municipality of Caxias, Maranhão state, northeastern Brazil. The APA of Inhamum is covered primarily by two distinct types of Cerrado vegetation (shrubby-arboreal and grassland) on the flatter terrain, with stands of buriti palms (Mauritia flexuosa L.) associated with watercourses, in depressions (Neres \& Conceição 2010).

\section{Acknowledgements}

We thank the Invertebrate Collection of INPA for allowing the use of photographic equipment used in this work. This study was financed in part by the Coordenação de Aperfeiçoamento de Pessoal de Nível Superior - Brasil (CAPES) - Finance Code 001 and FAPEAM-Programa POSGRAD.

\section{Authors' Contributions}

First author performed species identification and wrote the first version of this manuscript. Second and Third authors collected the specimen. All authors contributed substantially to paper writing and approved the final version on the manuscript. There is no conflict of interest between authors.

\section{References}

Braet, Y. (2016) Key to the genera of Doryctinae of the world. http://www.doryctinaekey.myspecies.info. Access on: 25.viii.2020.

Gadelha, S. S.; Nunes, J. F.; Oliveira, M. L. (2016) New genera, species and records of Doryctinae (Hymenoptera: Braconidae) from Brazil. Zootaxa, 4083: 359-370. doi: 10.11646/zootaxa.4083.3.2

Marsh, P. M. (1997) Doryctinae. In: Wharton, R. A., Marsh, P. M.; Sharkey, M. J. (Eds.), Manual of the New World genera of the family Braconidae (Hymenoptera), pp. 207-233. Washington, DC, The International Society of Hymenopterists. Special Publications 1.

Marsh, P. M. (2002) The Doryctinae of Costa Rica (Excluding The Genus Heterospilus). Memoirs of The American Entomological Institute, 70, 1-319.

Marsh, P. M.; Wild, A. L.; Whitfield, J. B. (2013) The Doryctinae (Braconidae) of Costa Rica: genera and species of the tribe Heterospilini. ZooKeys, 347: 1-474. doi: 10.3897/zookeys.347.6002

Neres L. P.; Conceição G. M. (2010) Florística e Fitossociologia da Área de Proteção Ambiental Municipal do Inhamum, Caxias, Maranhão, Brasil. Cadernos de Geocienciências, 7 (2): 122-130.

Shorthouse, D. P. (2010) SimpleMappr, an online tool to produce publication-quality point maps. https://www.simplemappr.net. Access on: 19.vii.2020.

Yu, D. S.; van Achterberg, C.; Horstmann, K. (2016) Taxapad 2016, Ichneumonoidea 2016. Database on flash-drive, Ottawa, Ontario, Canada.

Zaldívar-Riverón, A.; Belokobylskij, S. A.; Meza-Lázaro, R.; Pedraza-Lara, C.; García-París, M.; Meseguer, A. S. (2018) Species delimitation, global phylogeny and historical biogeography of the parasitoid wasp genus Spathius (Braconidae: Doryctinae) reveal multiple Oligocene-Miocene intercontinental dispersal events. Zoological Journal of the Linnean Society, 182 (4): 723-734. doi: 10.1093/ zoolinnean/zlx050 